\title{
Australian Journal of

\section{Morphometric diversity between fruits and seeds of mahogany trees (Swietenia macrophylla King.) from Parakanã Indigenous Land, Pará State, Brazil}

\author{
Noemi Vianna Martins Leão ${ }^{1^{*}}$, Sérgio Heitor Sousa Felipe ${ }^{2}$, Cláudio Emídio-Silva ${ }^{3}$, Antônia Camila dos \\ Santos Moraes ${ }^{4}$, Elizabeth Santos Cordeiro Shimizu ${ }^{1}$, Ricardo Gallo ${ }^{2}$, Alessandra Doce Dias de Freitas ${ }^{5}$, \\ Osvaldo Ryohei Kato ${ }^{6}$
}

\author{
${ }^{1}$ Embrapa Amazônia Oriental, Laboratório de Sementes Florestais, Belém, PA, Brazil \\ ${ }^{2}$ Universidade Federal de Viçosa, Laboratório de Cultura de Tecidos/BIOAGRO, Viçosa, MG, Brazil \\ ${ }^{3}$ Universidade do Estado do Pará, Núcleo de Formação Indígena, Belém, PA, Brazil \\ ${ }^{4}$ Universidade Federal Rural da Amazônia, Instituto de Ciências Agrárias, PA, Brazil \\ ${ }^{5}$ Universidade Federal do Pará, Faculdade de Engenharia Florestal, Altamira, PA, Brazil \\ ${ }^{6}$ Embrapa Amazônia Oriental, Projeto Tipitamba, Belém, PA, Brazil
}

\section{*Corresponding author: noemi.leao@embrapa.br}

\section{Abstract}

Morphometric studies of fruits and forest seeds may indicate the presence of variability among individuals of the same species. The objective of this study was to investigate the morphometric diversity of fruits and seeds of Swietenia macrophylla in 20 individuals belong to the Parakanã Indigenous Land, PA, Brazil. The following characteristics of the fruits, wingless seeds, and seeds without testa of the 20 trees were evaluated. Analysis of variance was performed on the collected data, followed by test of the means by Scott-Knott test. Genetic dissimilarity was assessed through means of the Unweighted Pair Group Method with Arithmetic Mean (UPGMA) grouping technique and canonical variables (CV). The results indicate high phenotypic diversity among mahogany fruits and seeds and the grouping of trees regardless is of the location of the indigenous village. Thus, mahogany trees have high genetic potential for germplasm conservation, seed harvesting, and breeding programs.

Keywords: fruit and seed biometry, forest seed, genetic conservation, phenotypic diversity, multivariate analysis.

Abbreviations: ANOVA_Analysis of variance, $\mathrm{CV}_{-}$Canonical variables, $\mathrm{CV}_{\mathrm{g}_{-}}$Coefficient of genetic variation, $\mathrm{D}^{2}{ }_{-}$Mahalanobis distance, FSL_Forest Seeds Laboratory, $\mathrm{h}^{2}$ _Heritability, IC_Intraclass, correlation, ITG_Itaygo'a, ITP_Itapeyga, ITW_Itaoenawa, ITY_Itaygara, IXG_Inaxyganga, LR_ Legal Reserve, MXW_Maroxewara, OYG_O'ayga, p_Significance level, PA_Pará State, PNA_Paranoawe, PNE_Paranoema, PNI_Paranoita, PNO_Parano'a, PNT_Paranatinga, PNW_Paranowaona, PPA_Permanent Preservation Areas, rS_Spearman non-parametric, SPU_Seed Processing Unit, SSRs_Microsatellite markers, UPGMA_Unweighted Pair Group Method with Arithmetic Mean, XRI_Xaraira, XTP_Xataopawa, $\sigma^{2}{ }_{\text {e_ }}$ Environmental variance, $\sigma_{g_{-}}^{2}$ Genetic variance, $\sigma_{p}^{2}$ Phenotypic variance.

Introduction

The world's natural forests amount to about 4 billion hectares, covering approximately $30 \%$ of the Earth's surface. Brazil is among the richest countries in forest area, accounting for approximately $12 \%$ of the global total. However, it is also the country that has registered the largest annual reduction in forest area between 2010 and 2015 (FAO, 2015); for example, the Brazilian state of Pará lost $22.70 \%$ of its total forest area until 2014 (INPE, 2015). This rate of deforestation leads to the reduction in biodiversity and an increase in the number of endangered species. The state of Pará has several native species of great commercial and ecological value, such as Swietenia macrophylla King. (Meliaceae), popularly known as Brazilian Mahogany or only Mahogany. This tree is the most valuable hardwood species in Neotropics (Lemes et al., 2010). S. macrophylla has been included in the list of endangered species in Brazil; this has been the result of two main factors: the predatory extraction and low population density and distribution in the highest deforestation rate areas in Brazilian Amazon (CNCFLORA, 2015). Gaining new insights into the characteristics of $S$. macrophylla may provide information that may facilitate and promote conservation of the species in a natural environment (e.g., potential for exploring nonwood forest products such as fruits and seeds). The natural populations of S. macrophylla can be found in the Parakanã Indigenous Land, State of Para, Brazil. The Parakanã Indigenous Land Homologation was established on March 5th, 1985 (Decree No. 91.028, 1985). One of the activities 
carried out by the indigenous Parakanã ethnic group is the harvesting of seeds of different tree species for commercialization (i.e., harvest of fruits and seeds of $S$. macrophylla). This harvesting activity is sustainable since it pertains to a non-wood forest resource, which would be useful in preserving the forest and natural timber populations of high commercial value. In addition, this activity is essential to support the growing demand of seeds for the recovery and/or restoration of Permanent Preservation Areas (PPA) and Legal Reserve (LR), as stipulated by the New Brazilian Forest Code (Leão et al., 2015a; Leão et al., 2015b), Law 12.651 (2012), and amended by Law 12.727 (2012).

Native seed biometrics can provide information that would be useful for (i) differentiating between different species of the same genus (Alves et al., 2007); (ii) investigating dispersion and seedling establishment (Fenner, 1993); (iii) conservation and exploitation of species (Gusmão et al., 2006); (iv) breeding program (Gonçalves et al., 2013); and (v) verifying the presence of genetic variability of different seeds lot that is necessity to in situ and ex situ conservation programs (Leão et al., 2016). Therefore, further research is essential to overcome the absence of biophysical information about fruits and seeds of natural populations of S. macrophylla in Brazilian Amazon (i.e., Pará State).

Studies on the fruit and seed morphometry of tree species have been carried out for different species such as Spondias sp. (Carvalho et al., 2008), Pinus pinea (Evaristo et al., 2008), Dimorphandra spp. (Sudré et al., 2011), Eugenia uniflora (Dias et al., 2011), Hancornia speciosa (Freitas et al., 2012), and Byrsonima dealbata (Lourenço et al., 2013), in order to detect the genetic variability with potential use for germplasm maintenance and breeding program.

Selecting desirable trees with high fruit yield and quality seeds as well as plants with high genetic variability and harvesting propagating material such as fruits and seeds in areas where S. macrophylla occur naturally will allow the composition of better germplasm banks, yield material for economically viable planting, and help preservation practice (Moura et al., 2013).

There have been no studies on the fruit and seed biometry of S. macrophylla and limited information is available on the potential of $S$. macrophylla trees in breeding studies; moreover, there is also a need for methods that guarantee seed commercialization with excellent standard of physiological and physical quality and genetic diversity, we decided to investigate morphometric diversity between mahogany fruits and seeds of different trees, aiming to generate information for the conservation, taxonomic, ecological, and silvicultural studies of $S$. macrophylla populations in the Parakanã Indigenous Land.

\section{Results and Discussion}

\section{Morphometric variations in fruits and seeds}

The results of the analyses were consistent and showed diversity among the morphometric aspects of the fruits, wingless seeds, and seeds without testa for the 20 evaluated trees. Univariate analysis formed different groups for each parameter measured, indicating presence of variability between trees (Table 1 and 2).

Biometric analysis of fruits and seeds of Pinus pinea (Evaristo et al., 2008), Dipteryx alata (Sano et al., 1999; Zuffo et al., 2014), Schizolobium parahyba (Freire et al., 2015), and Bertholletia excelsa (Texeira et al., 2015) in natural populations has shown high phenotypic variability, as observed in the current study.

According to the length of the mahogany fruits, the trees formed six groups, with tree 20 having the largest fruit and 9 having the shortest. According to the diameter of the fruits, the trees formed five groups, with the largest diameter being in the group containing trees $3,13,19$, and 20 and the smallest being in tree 11 . The fresh fruit mass formed four groups: trees 3 and 20 had the highest mass while trees 2,4 , 8,9 , and 11 had the lowest mass (Table 1 ).

Number of seeds per fruit formed four groups: trees 8 and 12 had more seeds while trees 2, 5, 9, 10, 11, and 13 had few seeds. According to seed mass per fruit, the trees were classified into five groups, with trees 14 and 19 having high mass and trees 4,7 , and 11 having the low mass (Table 1 ).

As per the number of well-formed seeds per fruit, the trees were categorized into two groups with trees $2,3,5,7,9,12$, $13,14,19,15,16$, and 17 having higher number of seeds while trees $1,4,6,8,10,11,18$, and 20 had lower number of seeds. The mass of well-formed seeds by fruit was the highest in trees 14 and 19 and the lowest in trees $4,7,8$, and 11 (Table 1).

The length of the wingless seeds was the highest in tree 6 and low in trees $1,2,3,4,7,8,9,10,12,16,17$ and 19 (Table 2). The width of the wingless seeds was greater in trees $3,4,5,6,8,9,13,14,16,19$, and 20 and less in trees 1 , $2,7,10,11,12,13,14$, and 15 (Table 2). The thickness of wingless seeds was greater for trees $6,8,13,14$, and 19 and low in trees 1, 2, 4, 9, 10, 11, 16, and 17 (Table 2).

Seed length without testa was greater in trees $1,2,3,5,6$, $8,9,10,13,14,15,18$, and 20 and low in trees $4,7,8,9,11$, $12,13,16,17$, and 19 (Table 2). The width of the seeds without testa was less in trees $1,2,3,5,6,8,9,10,13,14$, $15,16,19$, and 20 and greater in trees $4,7,11,12,17$, and 18 , whereas the thickness of the seeds without testa was greater in trees $8,11,12,13,14,15,18,19$, and 20 than in trees 3, 6, 7, 10, and 16 (Table 2).

In non-domesticated plants, morphometric variations in fruits and seeds are common (Sangalli et al., 2012) and morphometric variations among tree fruits and seeds in natural populations can be explained by the intrinsic genetic diversity of the individuals and the edaphoclimatic conditions that allows for phenotypic diversity (Zuffo et al., 2014; Leão et al., 2015a; Leão et al., 2017). The absence of genetic variability in forest seeds used in forest restoration projects affects the sustainability of the recovered plant communities (Souza et al., 2013).

Significant correlations ( $p \leq 0.05$ and $p \leq 0.01$ ) were observed on analysis of the variables through Pearson correlation (Table 3). We highlight the negative correlation between the number of well-shaped seeds and fruit length. From these results, we can infer that large fruits are not desirable, if they are not accompanied by large diameters. This would lead to a tendency to decrease the number of well-formed seeds. 
Table 1. Summary of variance analysis and comparison of means to fruit length (FL), fruit diameters (FD), fresh fruit mass (FM), number of seeds per fruit (NSF), fresh mass of the number of seeds per fruit (MNSF), number of well-formed seeds per fruit (NWSF), and fresh mass of the number of well-formed seeds per fruit (MWSF) from 20 trees of Swietenia macrophylla.

\begin{tabular}{|c|c|c|c|c|c|c|c|}
\hline \multirow{2}{*}{ Source of variation } & $\mathrm{FL}$ & FD & FM & NSF & MNSF & NWSF & MWSF \\
\hline & $\mathrm{mm}$ & $\mathrm{mm}$ & $\mathrm{g}$ & unit & $\mathrm{g}$ & unit & $\mathrm{g}$ \\
\hline $\mathrm{F}$ & $867.1^{* *}$ & $100.1^{* *}$ & $26326.3^{* *}$ & $32.3^{* *}$ & $150.6 * *$ & $48.8^{* *}$ & $139.5^{* *}$ \\
\hline Error & 30.8 & 5.8 & 942.4 & 2.9 & 7.5 & 10.0 & 8.9 \\
\hline Mean & 153.7 & 80.5 & 379.9 & 63.5 & 41.5 & 45.2 & 38.5 \\
\hline C.V. (\%) & 3.6 & 2.9 & 8.1 & 2.7 & 6.6 & 7.0 & 7.7 \\
\hline \multicolumn{8}{|l|}{ Tree } \\
\hline 1 & $156.5 \mathrm{~d}$ & $82.8 \mathrm{~b}$ & $427.2 \mathrm{~b}$ & $63.3 c$ & $45.5 \mathrm{c}$ & $44.2 \mathrm{~b}$ & $42.4 \mathrm{~b}$ \\
\hline 2 & $141.6 \mathrm{e}$ & $78.2 \mathrm{c}$ & $322.1 \mathrm{~d}$ & $61.3 \mathrm{~d}$ & $37.8 \mathrm{~d}$ & $44.9 \mathrm{a}$ & $35.4 \mathrm{c}$ \\
\hline 3 & $167.2 \mathrm{c}$ & $88.1 \mathrm{a}$ & $519.4 \mathrm{a}$ & $65.6 \mathrm{~b}$ & $46.8 \mathrm{~b}$ & $48.2 \mathrm{a}$ & $43.4 \mathrm{~b}$ \\
\hline 4 & $148.9 \mathrm{~d}$ & $73.4 \mathrm{~d}$ & $295.9 d$ & $62.5 \mathrm{c}$ & $33.5 \mathrm{e}$ & $43.2 \mathrm{~b}$ & $30.8 \mathrm{~d}$ \\
\hline 5 & $147.8 \mathrm{~d}$ & $81.9 \mathrm{~b}$ & $338.3 \mathrm{c}$ & $60.1 \mathrm{~d}$ & $42.6 \mathrm{c}$ & $48.0 \mathrm{a}$ & $40.4 \mathrm{~b}$ \\
\hline 6 & $178.4 \mathrm{~b}$ & $79.7 \mathrm{c}$ & $367.0 \mathrm{c}$ & $62.4 \mathrm{c}$ & $38.9 \mathrm{~d}$ & $38.8 \mathrm{~b}$ & $35.6 \mathrm{c}$ \\
\hline 7 & $148.6 \mathrm{~d}$ & $78.9 \mathrm{c}$ & $336.7 \mathrm{c}$ & $65.9 \mathrm{~b}$ & $31.8 \mathrm{e}$ & $46.5 \mathrm{a}$ & $29.5 d$ \\
\hline 8 & $145.2 \mathrm{e}$ & $74.2 \mathrm{~d}$ & $274.0 \mathrm{~d}$ & $68.5 \mathrm{a}$ & $36.8 \mathrm{~d}$ & $40.6 \mathrm{~b}$ & $33.0 \mathrm{~d}$ \\
\hline 9 & $133.9 \mathrm{f}$ & $78.2 \mathrm{c}$ & $302.9 \mathrm{~d}$ & $60.9 \mathrm{~d}$ & $38.6 \mathrm{~d}$ & $46.6 \mathrm{a}$ & $36.4 \mathrm{c}$ \\
\hline 10 & $167.4 \mathrm{c}$ & $83.3 \mathrm{~b}$ & $457.0 \mathrm{~b}$ & $61.1 \mathrm{~d}$ & $40.4 \mathrm{~d}$ & $43.1 \mathrm{~b}$ & $37.2 \mathrm{c}$ \\
\hline 11 & $151.9 \mathrm{~d}$ & $70.6 \mathrm{e}$ & $317.6 \mathrm{~d}$ & $61.6 \mathrm{~d}$ & $32.6 \mathrm{e}$ & $43.7 \mathrm{~b}$ & $30.4 \mathrm{~d}$ \\
\hline 12 & $140.0 \mathrm{e}$ & $82.9 \mathrm{~b}$ & $370.0 \mathrm{c}$ & $67.4 \mathrm{a}$ & $39.5 \mathrm{~d}$ & $48.2 \mathrm{a}$ & $37.2 \mathrm{c}$ \\
\hline 13 & $153.6 \mathrm{~d}$ & $86.2 \mathrm{a}$ & $440.3 \mathrm{~b}$ & $58.7 d$ & $42.6 \mathrm{c}$ & $45.6 \mathrm{a}$ & $40.9 \mathrm{~b}$ \\
\hline 14 & $147.8 \mathrm{~d}$ & $80.0 \mathrm{c}$ & $354.8 \mathrm{c}$ & $65.5 b$ & $50.8 \mathrm{a}$ & $50.3 \mathrm{a}$ & $48.4 \mathrm{a}$ \\
\hline 15 & $155.5 \mathrm{~d}$ & $79.8 \mathrm{c}$ & $373.8 c$ & $62.2 \mathrm{c}$ & $46.5 \mathrm{~b}$ & $45.3 \mathrm{a}$ & $43.8 \mathrm{~b}$ \\
\hline 16 & $144.4 \mathrm{e}$ & $82.2 \mathrm{~b}$ & $362.3 \mathrm{c}$ & $63.4 \mathrm{c}$ & $44.2 \mathrm{c}$ & $49.2 \mathrm{a}$ & $41.7 \mathrm{~b}$ \\
\hline 17 & $150.9 \mathrm{~d}$ & $78.4 \mathrm{c}$ & $357.2 \mathrm{c}$ & $63.0 \mathrm{c}$ & $38.3 \mathrm{~d}$ & $45.9 \mathrm{a}$ & $36.0 \mathrm{c}$ \\
\hline 18 & $162.0 \mathrm{c}$ & $79.2 \mathrm{c}$ & $390.0 \mathrm{c}$ & $65.2 \mathrm{~b}$ & $46.6 \mathrm{~b}$ & $41.6 \mathrm{~b}$ & $40.8 \mathrm{~b}$ \\
\hline 19 & $146.2 \mathrm{e}$ & $85.6 \mathrm{a}$ & $441.5 \mathrm{~b}$ & $65.2 \mathrm{~b}$ & $48.8 \mathrm{a}$ & $48.8 \mathrm{a}$ & $46.7 \mathrm{a}$ \\
\hline 20 & $187.7 \mathrm{a}$ & $86.3 \mathrm{a}$ & $547.5 \mathrm{a}$ & $65.2 \mathrm{~b}$ & $46.6 \mathrm{~b}$ & $41.6 \mathrm{~b}$ & $40.8 \mathrm{~b}$ \\
\hline
\end{tabular}

** - Significant ( $p \leq 0.01)$. Means followed by the same letter in the column do not differ inwardly by the Scott and Knott test, at $1 \%$.
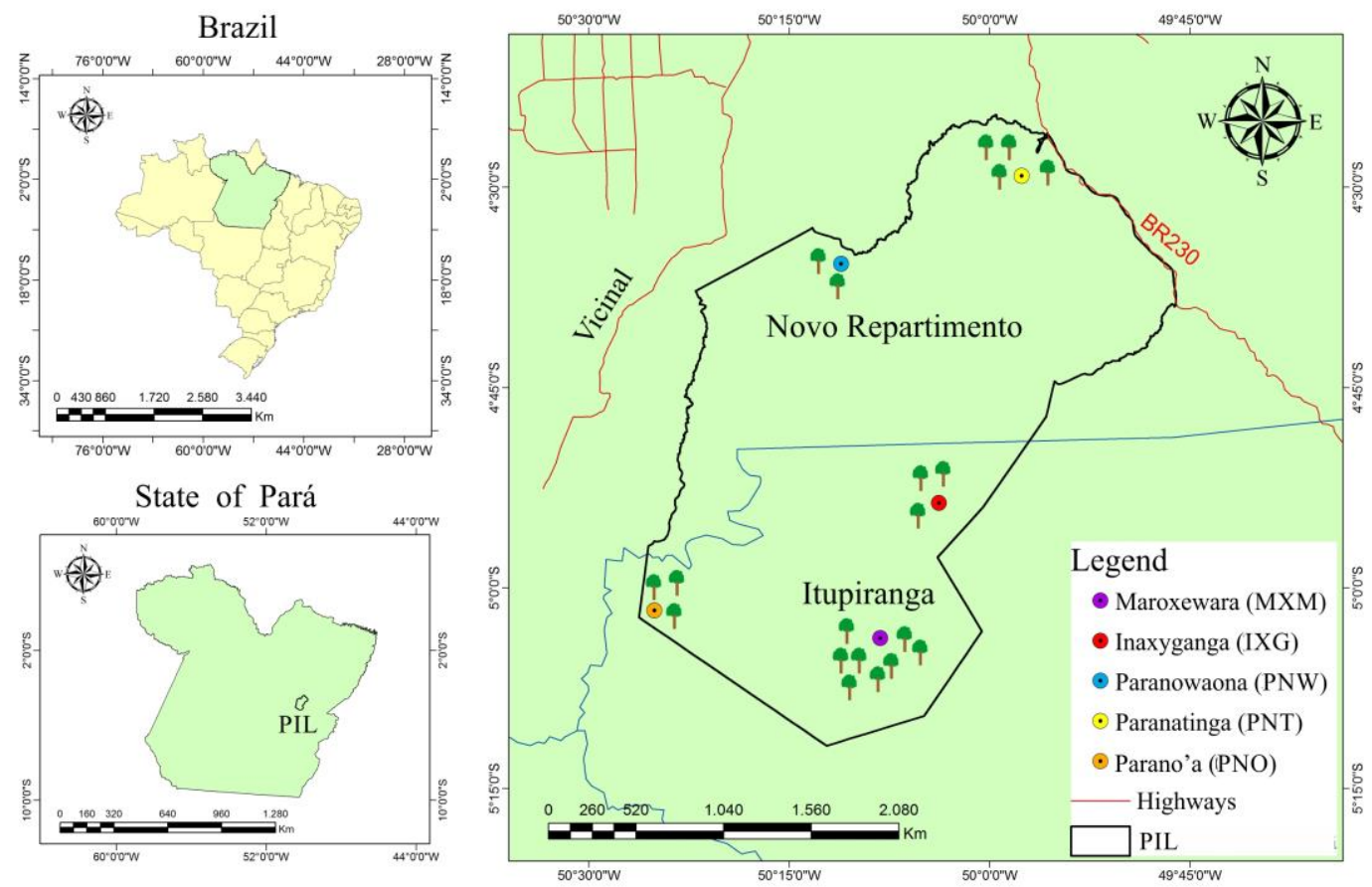

Fig 1. Location of the Parakanã Indigenous Land (PIL) and the Maroxewara (MXM), Inaxyganga (IXG), Paranowaona (PNW), Paranatinga (PNT), and Parano'a (PNO) indigenous villages. 
Table 2. Summary of variance analysis and comparison of means to wingless seed length (WSL); wingless seed width (WSW), wingless seed thickness (WST), seed length without testa (SLWT), seed width without testa (SWWT), and seed thickness without testa (STWT) from 20 trees of Swietenia macrophylla.

\begin{tabular}{|c|c|c|c|c|c|c|}
\hline \multirow{2}{*}{ Source of variation } & WSL & WSW & WST & SLWT & SWWT & STWT \\
\hline & $\mathrm{mm}$ & $\mathrm{mm}$ & $\mathrm{mm}$ & $\mathrm{mm}$ & $\mathrm{mm}$ & $\mathrm{mm}$ \\
\hline $\mathrm{F}$ & $28.0 * *$ & $3.8^{* *}$ & $1.3^{* *}$ & $19.1^{* *}$ & $1.5^{* *}$ & $0.6 * *$ \\
\hline Error & 4.4 & 1.1 & 0.2 & 3.4 & 0.4 & 0.1 \\
\hline Mean & 29.2 & 16.8 & 6.4 & 21.2 & 10.8 & 3.8 \\
\hline C.V. (\%) & 7.2 & 6.1 & 7.6 & 8.7 & 5.6 & 7.2 \\
\hline \multicolumn{7}{|l|}{ Tree } \\
\hline 1 & $28.1 \mathrm{c}$ & $15.4 \mathrm{~b}$ & $5.5 \mathrm{c}$ & $21.7 \mathrm{a}$ & $10.8 \mathrm{a}$ & $3.7 \mathrm{~b}$ \\
\hline 2 & $27.4 \mathrm{c}$ & $16.4 \mathrm{~b}$ & $5.6 \mathrm{c}$ & $22.1 \mathrm{a}$ & $10.9 \mathrm{a}$ & $3.7 b$ \\
\hline 3 & $27.9 \mathrm{c}$ & $17.1 \mathrm{a}$ & $5.7 \mathrm{c}$ & $22.0 \mathrm{a}$ & $10.8 \mathrm{a}$ & $3.4 c$ \\
\hline 4 & $27.9 \mathrm{c}$ & $17.0 \mathrm{a}$ & $5.9 \mathrm{c}$ & $18.4 \mathrm{~b}$ & $10.3 \mathrm{~b}$ & $3.7 b$ \\
\hline 5 & $31.6 \mathrm{~b}$ & $18.2 \mathrm{a}$ & $5.9 \mathrm{c}$ & $23.5 \mathrm{a}$ & $11.8 \mathrm{a}$ & $3.5 \mathrm{~b}$ \\
\hline 6 & $35.3 \mathrm{a}$ & $18.5 \mathrm{a}$ & $6.0 \mathrm{c}$ & $23.7 \mathrm{a}$ & $11.1 \mathrm{a}$ & $3.3 c$ \\
\hline 7 & $24.5 \mathrm{c}$ & $16.1 \mathrm{~b}$ & $6.2 \mathrm{c}$ & $17.9 \mathrm{~b}$ & $10.1 \mathrm{~b}$ & $3.4 \mathrm{c}$ \\
\hline 8 & $27.9 \mathrm{c}$ & $17.3 \mathrm{a}$ & $6.2 \mathrm{c}$ & $19.1 \mathrm{~b}$ & $11.0 \mathrm{a}$ & $3.9 \mathrm{a}$ \\
\hline 9 & $28.3 \mathrm{c}$ & $17.3 \mathrm{a}$ & $6.3 \mathrm{~b}$ & $20.3 \mathrm{~b}$ & $11.6 \mathrm{a}$ & $3.6 \mathrm{~b}$ \\
\hline 10 & $29.3 \mathrm{c}$ & $16.6 \mathrm{~b}$ & $6.4 \mathrm{~b}$ & $22.8 \mathrm{a}$ & $11.0 \mathrm{a}$ & $3.4 \mathrm{c}$ \\
\hline 11 & $29.9 \mathrm{~b}$ & $15.5 \mathrm{~b}$ & $6.4 b$ & $20.9 \mathrm{~b}$ & $9.8 \mathrm{~b}$ & $4.1 \mathrm{a}$ \\
\hline 12 & $27.0 \mathrm{c}$ & $15.9 \mathrm{~b}$ & $6.5 \mathrm{~b}$ & $18.5 \mathrm{~b}$ & $10.5 \mathrm{~b}$ & $4.1 \mathrm{a}$ \\
\hline 13 & $30.3 \mathrm{~b}$ & $17.0 \mathrm{a}$ & $6.5 b$ & $19.5 \mathrm{~b}$ & $10.7 \mathrm{a}$ & $4.1 \mathrm{a}$ \\
\hline 14 & $31.6 \mathrm{~b}$ & $17.9 \mathrm{a}$ & $6.5 b$ & $21.9 \mathrm{a}$ & $11.4 \mathrm{a}$ & $4.1 \mathrm{a}$ \\
\hline 15 & 29.8 b & $16.6 \mathrm{~b}$ & $6.6 \mathrm{~b}$ & $21.8 \mathrm{a}$ & $10.8 \mathrm{a}$ & 3.9 a \\
\hline 16 & $29.3 \mathrm{c}$ & $17.2 \mathrm{a}$ & 6.9 a & $21.0 \mathrm{~b}$ & $11.1 \mathrm{a}$ & $3.3 c$ \\
\hline 17 & $26.8 \mathrm{c}$ & $15.4 \mathrm{~b}$ & $6.9 \mathrm{a}$ & $20.2 \mathrm{~b}$ & $10.1 \mathrm{~b}$ & $3.7 b$ \\
\hline 18 & $30.9 \mathrm{~b}$ & $16.1 b$ & $7.1 \mathrm{a}$ & $24.7 \mathrm{a}$ & $9.8 \mathrm{~b}$ & $3.9 \mathrm{a}$ \\
\hline 19 & $27.5 \mathrm{c}$ & $17.1 \mathrm{a}$ & $7.1 \mathrm{a}$ & $20.0 \mathrm{~b}$ & $11.0 \mathrm{a}$ & $4.4 \mathrm{a}$ \\
\hline 20 & $32.0 \mathrm{~b}$ & $16.9 \mathrm{a}$ & $7.3 \mathrm{a}$ & $23.7 \mathrm{a}$ & $10.7 \mathrm{a}$ & $4.1 \mathrm{a}$ \\
\hline
\end{tabular}

** - Significant $(p \leq 0.01)$. Means followed by the same letter in the column do not differ inwardly by the Scott and Knott test, at $1 \%$.

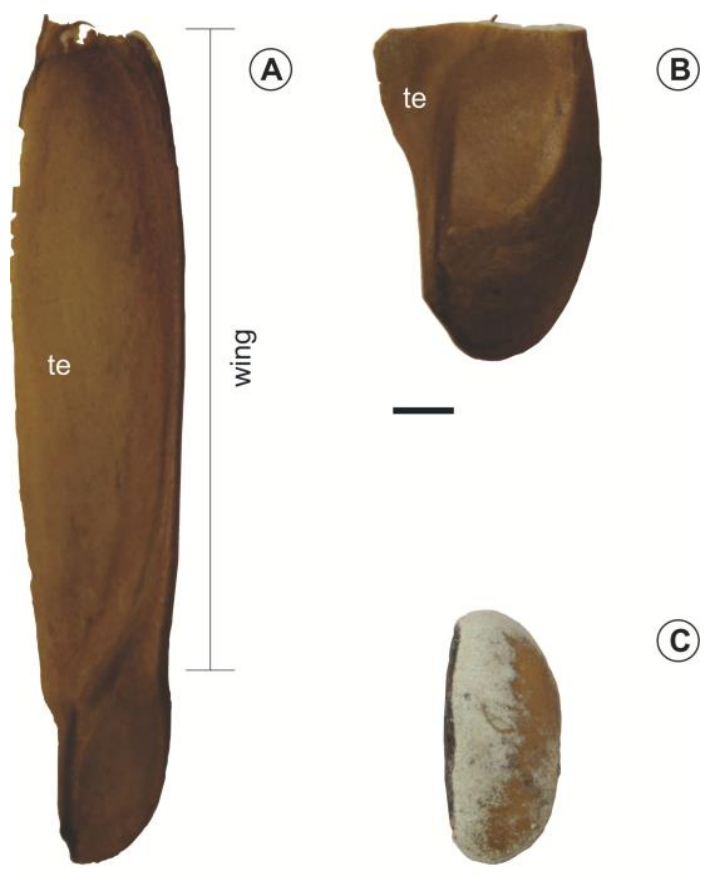

Fig 2. Mahogany seed: (A) winged seed, (B) wingless seed and (C) seed without testa. (te: testa). Scale bars: $20 \mathrm{~mm}(\mathrm{~A}) ; 5 \mathrm{~mm}(\mathrm{~B}$ and C). 
Table 3. Pearson's correlation coefficient ( $r$ ) among fruit length (FL), fruit diameters (FD), fresh fruit mass (FM), number of seeds per fruit (NSF), fresh mass of the number of seeds per fruit (MNSF), number of well-formed seeds per fruit (NWSF), fresh mass of the number of well-formed seeds per fruit (MWSF), wingless seed length (WSL); wingless seed width (WSW), wingless seed thickness (WST), seed length without testa (SLWT), seed width without testa (SWWT), and seed thickness without testa (STWT) from 20 trees of Swietenia macrophylla.

\begin{tabular}{|c|c|c|c|c|c|c|c|c|c|c|c|c|}
\hline & FD & FM & NSF & MNSF & NWSF & MWSF & WSL & WSW & WST & SLWT & SWWT & STWT \\
\hline $\mathrm{FL}$ & $0.37^{\text {ns }}$ & $0.70 * *$ & $0.02^{\mathrm{ns}}$ & $0.28^{\mathrm{ns}}$ & $-0.56^{*}$ & $0.03^{\mathrm{ns}}$ & $0.57^{* *}$ & $0.12^{\mathrm{ns}}$ & $0.21^{\mathrm{ns}}$ & $0.61^{* *}$ & $-0.16^{\text {ns }}$ & $-0.13^{\mathrm{ns}}$ \\
\hline FD & & $0.84^{* *}$ & $0.03^{\mathrm{ns}}$ & $0.68^{* *}$ & $0.35^{\text {ns }}$ & $0.71^{* *}$ & $0.10^{\mathrm{ns}}$ & $0.18^{\mathrm{ns}}$ & $0.16^{\mathrm{ns}}$ & $0.26^{\mathrm{ns}}$ & $0.32^{\text {ns }}$ & $0.02^{\mathrm{ns}}$ \\
\hline FM & & & $0.06^{\mathrm{ns}}$ & $0.58^{* *}$ & $0.03^{\mathrm{ns}}$ & $0.52^{* *}$ & $0.19^{\mathrm{ns}}$ & $-0.04^{\mathrm{ns}}$ & $0.10^{\mathrm{ns}}$ & $0.40^{\text {ns }}$ & $-0.02^{\mathrm{ns}}$ & $0.12^{\mathrm{ns}}$ \\
\hline NSF & & & & $0.14^{\mathrm{ns}}$ & $0.03^{\mathrm{ns}}$ & $-0.01^{\mathrm{ns}}$ & $-0.29^{\mathrm{ns}}$ & $-0.11^{\mathrm{ns}}$ & $0.21^{\mathrm{ns}}$ & $-0.22^{\mathrm{ns}}$ & $-0.21^{\mathrm{ns}}$ & $0.24^{\mathrm{ns}}$ \\
\hline MNSF & & & & & $0.29^{\mathrm{ns}}$ & $0.85^{* *}$ & $0.38^{\mathrm{ns}}$ & $0.32^{\mathrm{ns}}$ & $0.18^{\mathrm{ns}}$ & $0.57^{* *}$ & $0.42^{\mathrm{ns}}$ & $0.23^{\mathrm{ns}}$ \\
\hline NWSF & & & & & & $0.61^{* *}$ & $-0.36^{\mathrm{ns}}$ & $0.04^{\mathrm{ns}}$ & $-0.14^{\mathrm{ns}}$ & $-0.28^{\mathrm{ns}}$ & $0.31^{\mathrm{ns}}$ & $0.11^{\mathrm{ns}}$ \\
\hline MWSF & & & & & & & $0.19^{\mathrm{ns}}$ & $0.23^{\mathrm{ns}}$ & $0.15^{\mathrm{ns}}$ & $0.32^{\mathrm{ns}}$ & $0.47^{*}$ & $0.21^{\mathrm{ns}}$ \\
\hline WSL & & & & & & & & $0.59 * *$ & $0.41^{\mathrm{ns}}$ & $0.72^{* *}$ & $0.32^{\mathrm{ns}}$ & $-0.02^{\text {ns }}$ \\
\hline WSW & & & & & & & & & $0.56^{*}$ & $0.26^{\mathrm{ns}}$ & $0.75 * *$ & $-0.22^{\mathrm{ns}}$ \\
\hline WST & & & & & & & & & & $-0.02^{\text {ns }}$ & $0.16^{\mathrm{ns}}$ & $0.38^{\mathrm{ns}}$ \\
\hline SLWT & & & & & & & & & & & $0.22^{\mathrm{ns}}$ & $-0.17^{\mathrm{ns}}$ \\
\hline SWWT & & & & & & & & & & & & $-0.20^{\mathrm{ns}}$ \\
\hline
\end{tabular}

ns - non significant; ${ }^{*}$ significant $(p \leq 0.05) ;{ }^{* *}$ significant $(\mathrm{p} \leq 0.01)$

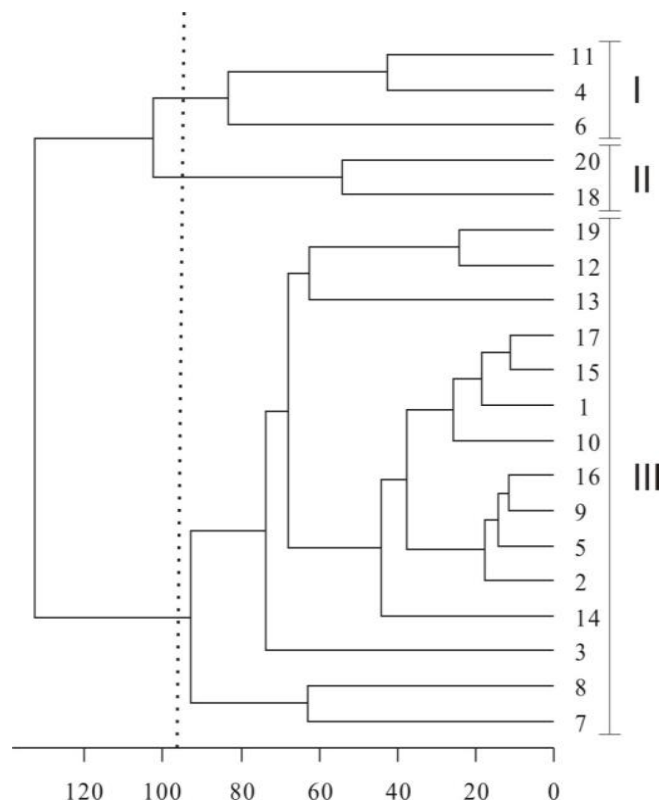

Fig 3. Illustrative Dendrogram of dissimilarity standard established by UPGMA, based on 13 traits evaluated in fruits and seeds of 20 trees of Swietenia macrophylla.

Table 4. Estimates of phenotypic variance $\left(\sigma_{\mathrm{f}}^{2}\right)$, environmental variance $\left(\sigma^{2}{ }_{\mathrm{a}}\right)$, genotypic variance $\left(\sigma_{\mathrm{g}}^{2}\right)$, genetic variation coefficient $\left(\mathrm{CV}_{\mathrm{g}}\right)$, heritability $\left(\mathrm{h}^{2}\right)$, and intraclass correlation (IC), on 13 traits evaluated in fruits and seeds of 20 trees of Swietenia macrophylla.

\begin{tabular}{lllllll}
\hline Variables & $\sigma^{*}{ }_{\mathrm{f}}$ & $\sigma_{\mathrm{a}}^{2}$ & $\sigma_{\mathrm{g}}^{2}$ & $\mathrm{CV}_{\mathrm{g}}$ & $\mathrm{h}^{2}$ & $\mathrm{Cl}$ \\
\hline FL & 173.42 & 6.17 & 167.25 & 8.41 & 96.44 & 84.44 \\
FD & 20.02 & 1.16 & 18.87 & 5.40 & 94.22 & 76.53 \\
FM & 5265.25 & 188.49 & 5076.77 & 18.76 & 96.42 & 84.34 \\
NSF & 6.45 & 0.58 & 5.88 & 3.82 & 91.06 & 67.07 \\
MNSF & $3.3010^{-5}$ & $3.0010^{-6}$ & $3.0010^{-5}$ & 13.18 & 91.66 & 68.72 \\
NWSF & 9.76 & 2.00 & 7.76 & 6.16 & 79.50 & 43.68 \\
MWSF & $3.1010^{-5}$ & $3.0010^{-6}$ & $2.8010^{-5}$ & 13.72 & 91.07 & 67.09 \\
WSL & 5.60 & 0.89 & 4.72 & 7.44 & 84.17 & 51.54 \\
WSW & 0.76 & 0.21 & 0.55 & 4.41 & 72.26 & 34.26 \\
WST & 0.27 & 0.05 & 0.22 & 7.32 & 82.09 & 47.83 \\
SLWT & 3.81 & 0.68 & 3.13 & 8.34 & 82.06 & 47.78 \\
SWWT & 0.30 & 0.07 & 0.23 & 4.47 & 76.14 & 38.96 \\
STWT & 0.11 & 0.01 & 0.10 & 8.26 & 86.88 & 56.98 \\
\hline
\end{tabular}

"Fruit length (FL), fruit diameters (FD), fresh fruit mass (FM), number of seeds per fruit (NSF), fresh mass of the number of seeds per fruit (MNSF), number of well-formed seeds per fruit (NWSF), fresh mass of the number of well-formed seeds per fruit (MWSF), wingless seed length (WSL); wingless seed width (WSW), wingless seed thickness (WST), seed length without testa (SLWT), seed width without testa (SWWT), and seed thickness without testa (STWT). 
Table 5. Relevant contribution of variables for the diversity. Singh (1981) criteria based on $D^{2}$ of Mahalanobis.

\begin{tabular}{ll}
\hline Variables* & Relative Importance (\%) \\
\hline FL & 26.68 \\
FM & 21.47 \\
MNSF & 8.13 \\
WSL & 8.02 \\
NSF & 7.62 \\
FD & 7.26 \\
MWSF & 4.60 \\
SLWT & 4.44 \\
SWWT & 3.88 \\
STWT & 3.31 \\
WST & 1.87 \\
NWSF & 1.52 \\
WSW & 1.20 \\
\hline
\end{tabular}

*Fruit length (FL), fresh fruit mass (FM), fresh mass of the number of seeds per fruit (MNSF), wingless seed length (WSL), number of seeds per fruit (NSF), fruit diameters (FD), fresh mass of the number of well-formed seeds per fruit (MWSF), seed length without testa (SLWT), seed width without testa (SWWT), seed thickness without testa (STWT), wingless seed thickness (WST), number of well-formed seeds per fruit (NWSF), and wingless seed width (WSW).

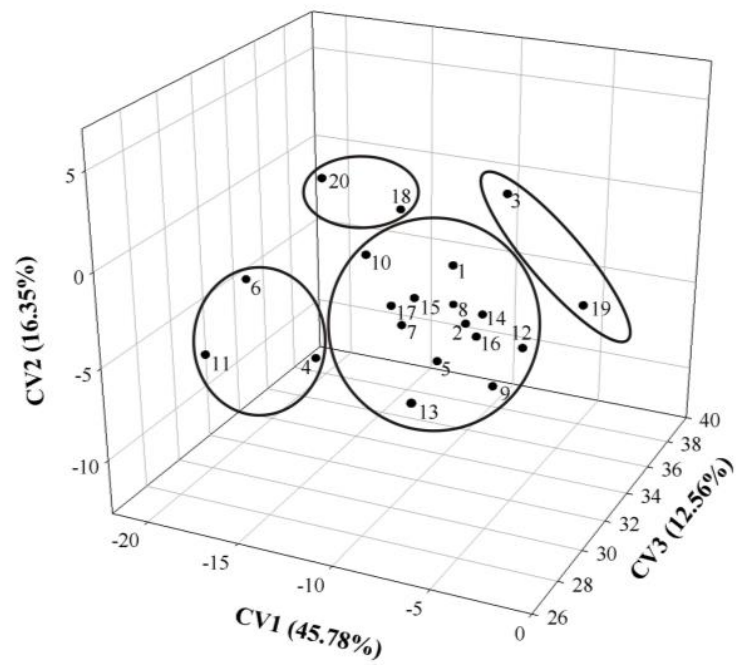

Fig 5. Dispersion of score graphics in relation to representative axes of the canonical variables (CV1, CV2, and CV3), on 13 traits evaluated (see in table 5, variables) in fruits and seeds of 20 trees of Swietenia macrophylla.

Table 6. Means to fruit length (FL), fruit diameters (FD), fresh fruit mass (FM), number of seeds per fruit (NSF), fresh mass of the number of seeds per fruit (MNSF), number of well-formed seeds per fruit (NWSF), fresh mass of the number of well-formed seeds per fruit (MWSF), wingless seed length (WSL); wingless seed width (WSW), wingless seed thickness (WST), seed length without testa (SLWT), seed width without testa (SWWT), and seed thickness without testa (STWT) of the three groups generated by the UPGMA method from 20 trees of Swietenia macrophylla.

\begin{tabular}{|c|c|c|c|c|c|c|c|c|c|c|c|c|c|}
\hline \multirow{2}{*}{ Group } & $\mathrm{FL}$ & FD & FM & NSF & MNSF & NWSF & MWSF & WSL & WSW & WST & SLWT & SWWT & STWT \\
\hline & $\mathrm{mm}$ & $\mathrm{mm}$ & $\mathrm{g}$ & unit & $\mathrm{g}$ & unit & $\mathrm{g}$ & $\mathrm{mm}$ & $\mathrm{mm}$ & $\mathrm{mm}$ & $\mathrm{mm}$ & $\mathrm{mm}$ & $\mathrm{mm}$ \\
\hline 1 & 159.7 & 74.6 & 326.8 & 62.1 & 35.0 & 41.9 & 32.3 & 31.0 & 17.0 & 6.6 & 21.0 & 10.4 & 3.7 \\
\hline 2 & 174.9 & 82.7 & 468.8 & 65.2 & 46.6 & 41.6 & 40.8 & 31.5 & 16.5 & 6.4 & 24.2 & 10.2 & 4.1 \\
\hline 3 & 149.7 & 81.4 & 378.5 & 63.5 & 42.1 & 46.3 & 39.5 & 28.5 & 16.8 & 6.3 & 20.8 & 10.9 & 3.8 \\
\hline
\end{tabular}

\section{Genetic diversity in fruits and seeds}

Estimation of phenotypic variance, environmental variance, genetic variance, intraclass correlation, heritability, and coefficient of genetic variation provides an insight into the genetic potential of 20 mahogany trees to be used in conservation and breeding studies (Table 4).

The observed variations in biometric characteristics of Schinus terebinthifolius fruits and seeds have been attributed to the genetic characteristics of each individual (Souza et al., 2013). Similar results were found in this study. Among the components of variance, the values of genotypic variance $\left(\sigma_{\mathrm{g}}^{2}\right)$ were higher than those of the environmental variance $\left(\sigma^{2}\right)$ for all characteristics analyzed (Table 4). This implies that there is genetic divergence between fruits and seeds of mahogany trees. Although there is an environmental influence, the genotype variation is the main cause of the different sizes of mahogany seeds and fruits.

The genotype coefficient of variation $\left(\mathrm{CV}_{\mathrm{g}}\right)$ was high for the variables related to the mass: fresh fruit mass, fresh mass of the number of seeds per fruit, and mass of the number of well-formed seeds (Table 4). When values are high for genotypic variation, there is a possibility of significant gains in the selection process in breeding (Cardoso et al., 2009). 
The coefficient of heritability $\left(\mathrm{h}^{2}\right)$ showed high values. The lowest coefficient was observed for the wingless seed width with value at $72.26 \%$ and the highest coefficients were observed for fruit length, fruit diameter, fruit mass, and number of seeds per fruit, with values above $94 \%$ (Table 4). The greater the estimated heritability value, the greater was the chance of success in the selection and of these characteristics being passed on to the progenies (Vasconcelos et al., 2012).

The intraclass correlation (IC) was considerable for fruit length, diameter, and mass, with values being 84.43; 76.53 and 84.34 , respectively (Table 4). With respect to the other characteristics, such as number of seeds per fruit, number of well-formed seeds per fruit, wingless seed length, wingless seed thickness, length without seed testa, and thickness of seed without testa, IC was satisfactory, indicating high variability (Table 4). The wingless seed width and width of seed without testa showed low IC, indicating low variability (Table 4).

The results of this study show high phenotypic diversity for the evaluated characteristics, mainly contributed by the genetic divergence among mahogany trees. These results corroborate partly the observations made by Lemes et al. (2003) who studied genetic diversity in natural mahogany populations in the Brazilian Amazon using microsatellite markers (SSRs) and found genetic divergence among populations. These same authors emphasize the importance of maintaining populations in their diverse habitats, mainly in areas with different types of topographies and soils.

Fruit length, fruit diameter, fresh fruit mass, number of seeds per fruit, fresh mass of the number of seeds per fruit, and wingless seed length contributed to $79.18 \%$ of the genetic divergence. Fruit length and fresh fruit mass showed greater relative importance, contributing $26.68 \%$ and $21.47 \%$, respectively (Table 5 ).

Cluster analysis of the 20 mahogany trees based on genetic characteristics of generalized Mahalanobis distance $\left(D^{2}\right)$ revealed three groups (Fig 3): Group 1 (formed by trees 4,6 , and 11), Group 2 (formed by trees 18 and 20), and Group 3 (formed by trees 1, 2, 3, 5, 7, 8, 9, 10, 12, 13, 14, 15, 16,17 , and 19). This grouping was independent of the place of origin (indigenous villages). The results of this study are similar to those reported by Moraes and Alves (2002), in which the grouping between trees was independent of the geographical origin. Their analysis was based on the morphometric variables of fruits and diaspores of two genera of Cryptocarya. The formation of distinct groups indicates the presence of genetic variability among individuals of the same species (Sano et al., 1999).

Group 1 (trees 4, 6, and 11) included trees that are located only in the village Maroxewara (MXW), which is to the south of Parakanã Indigenous Land; this group had the highest averages for wingless seed width and wingless seed thickness (Table 6). Since three trees were from the same village, proximity could be an explanation of this grouping. Group 2 (trees 18 and 20) showed the highest averages for the characteristics related to fruit size and mass, number of seeds per fruit, and seed mass per fruit (Table 6). Notably, tree 18 is located in the Paranatinga village (PNT) from the north region and tree 20 in the Paranowaona village (PNW) from the southern region of Parakanã Indigenous Land. This result shows that even under different physical conditions, trees can be grouped by phenotypic similarities.

Group 3 was composed by the majority of the trees (trees $1,2,3,5,7,8,9,10,12,13,14,15,16,17$, and 19). The trees in this group included those from the village Inaxyganga (IXG) (tree 1, 2, and 3), the majority from the village Maroxewara (MXW) (tree 5, 7, 8, 9 and 10), two from the village Parano (PNO) (trees 12 and 13), the majority of the trees from the village Paranatinga (PNT) (tree 15, 16, and 17) and one tree from the village Paranowaona (PNW) (tree 19). This group deserves to be highlighted because it presents the highest mean number of well-formed seeds per fruit (Table 6). This is a characteristic that needs to be further explored in breeding programs.

Analysis of the canonical variables showed that there was phenotypic diversity among the fruits and seeds (Fig 5). The first three canonical variables explain $74.69 \%$ of the total variance. The variables that contributed the most to this explanation were fruit length, fresh fruit mass, and wingless seed length, in that order. The variable width of non-winged seeds was a less significant contributor. The dispersion pattern of 20 trees in canonical variables graphic (Fig 5), generated from the first three main components, was consistent with the clustering pattern obtained by the UPGMA method. The only exception was the trees 3 and 19, previously present in group 3; however, the former was changed to a new group.

\section{Materials and methods}

\section{Study area}

Fruits and seeds of Brazilian mahogany were harvested in the Parakanã Indigenous Land, which is located in the mesoregion of Southeastern Pará and microregion of Tucuruí, in the cities of New Repartimento and Itupiranga, Pará State (PA), Brazil (Fig 1).

The Parakanã Indigenous Land has a total area of 351,697 hectare and comprises 15 indigenous villages (Fig 1): Paranowaona (PNW), Paranatinga (PNT), Parano'a (PNO), Paranoawe (PNA), Itaygo'a (ITG), Inaxyganga (IXG), Maroxewara (MXW), Itapeyga (ITP), Paranoita (PNI), Itaoenawa (ITW), O'ayga (OYG), Paranoema (PNE), Itaygara (ITY), Xataopawa (XTP), and Xaraira (XRI). The dominant climate is type Am (characterized by an annual average temperature of $26{ }^{\circ} \mathrm{C}$ and rainfall of approximately 2,300 $\mathrm{mm}$ per year) as per Koppen classification.

\section{Selection of trees, harvesting fruits and seeds, and seeds processing}

Mahogany trees were selected from five indigenous villages (Fig 1): Inaxyganga (trees 1, 2, and 3), Maroxewara (trees 4, $5,6,7,8,9,10$, and 11), Parano'a (trees 12, 13, and 14), Paranatinga (trees 15, 16, 17, and 18), and Paranowaona (trees 19 and 20). The phenotypic characteristics of the stem trees (height ranging 33.0 to $47.0 \mathrm{~m}$ and diameter ranging 24.0 to $127.3 \mathrm{~cm}$ ) and fruit production were considered since they are used by the indigenous people to harvest fruits and seeds for commercialization. 
Fruits and seeds harvesting was performed when the trees were beginning seed dissemination. Because the fruits are dehiscent and the winged seeds disperse via the wind, harvesting was carried out while the fruits were closed, using the rappel technique with a tree trimmer by Leão et al. (2011). The fruits harvested were packed in bags and dispatched to the Seed Processing Unit (SPU) of the Forest Seeds Laboratory (FSL), PA, Brazil. Once the material arrived in the SPU, a ventilated place and covered, the fruits were scattered on a tarpaulin for a spontaneous opening. Then, the extraction, processing, and measurement of the seeds were performed. The processing consisted of the removal of the seed wings (Fig 2A) since these seeds are marketed without wings (Fig 2B).

\section{Biomass and morphometric measurements}

Fruit biometry was measured after fruit arrival at SPU, before spontaneous opening. Twenty-five fruits were randomly selected from each mother tree. For evaluation of seed characteristics, two each of large, two medium, and small fruits were collected from each mother tree and 10 seeds of each fruit were selected randomly, totaling 60 seeds. First, wingless seeds (Fig 2B), and then seeds without testa (Fig 2C) were measured for each mother tree.

Samples of the 20 mother trees were evaluated for the characteristics of fruits, wingless seeds, and seeds without testa: fruit length; fruit diameters; fresh fruit mass; number of seeds per fruit, fresh mass of the number of seeds per fruit, number of well-formed seeds per fruit, fresh mass of the number of well-formed seeds per fruit, wingless seed length; wingless seed width, wingless seed thickness, seed length without testa, seed width without testa, and seed thickness without testa.

The biometry of fruits and seeds was measured with tree caliper (Nakamura, Japan) and digital caliper rule (Digital Mitutoyo Absolute Digimatic, Japan), respectively. Fruits and seed length were measured from the apex to the base. Fruit diameter and wingless seeds and width and thickness of seeds without testa were measured in the intermediate region. The number of seeds per fruit was obtained by counting the total number of seeds contained in each of the 25 fruits harvested from each mother tree, and separating the well-formed seeds from each fruit and counting.

\section{Experimental design and statistical analysis}

experimental design was completely random, consisting of 5 replications per mother tree and the experimental unit was equal to 5 and 15 per fruits and seeds, respectively. The data were subjected to analysis of variance (ANOVA); when there was significant difference, the test of Scott and Knott (1974) was applied $(p<0.01)$. The correlation coefficient of Spearman non-parametric $(r S)$ and the significance level $(p)$ among the variables were calculated. The phenotypic variance $\left(\sigma_{p}^{2}\right)$, environmental variance $\left(\sigma^{2}\right)$, genetic variance $\left(\sigma_{\mathrm{g}}^{2}\right)$, intraclass correlation (IC), heritability $\left(\mathrm{h}^{2}\right)$, and coefficient of genetic variation $\left(\mathrm{CV}_{\mathrm{g}}\right)$ were estimated through the ANOVA mean square using the expressions provided by Vencovsky and Barriga (1992). To study the genetic diversity, the generalized distance of Mahalanobis was estimated, followed by analysis of grouping and graphic dispersion, by using the Unweighted Pair Group Method with Arithmetic Mean (UPGMA) method and canonical variables (CV), respectively. The cut-off point in the dendrogram was defined by Mojema (1977). The Singh method (1981) was used to evaluate the relative importance of the 12 evaluated characteristics. Data were analyzed using the softwares Genes (Cruz, 2013) and R (R Development Core Team, 2006).

\section{Conclusion}

Our findings indicate high phenotypic diversity among mahogany fruits and seeds, the grouping of trees regardless of the location of the indigenous village, and suggest that mahogany trees indeed have high genetic potential for germplasm conservation, seed harvesting, and breeding programs. In addition, the conservation of mahogany populations of the Parakanã Indigenous Land is very important to meet the increasing demand for native seeds with high genetic variability and known origin.

\section{Acknowledgements}

The authors thank the Amazonas Paraense Foundation for Research Support (Fapespa) for financial support. We also thank the Parakanã Program/Eletronorte for technical support.

\section{References}

Alves EU, Bruno Alcântara RL, Alves AU, Cardoso EA, Galindo EA, Júnior JMB (2007) Germinação e biometria de frutos e sementes de Bauhinia divaricata L. (Leguminosae). Sitientibus Ser Cienc Biol. 7(3): 193-198.

Cardoso DL, Silva RF, Pereira MG, Viana AP, Araújo EF (2009) Diversidade genética e parâmetros genéticos relacionados à qualidade fisiológica de sementes em germoplasma de mamoeiro. Rev Ceres. 56(5): 572-579.

Carvalho PCL, Ritzinger R, Soares Filho, WS, Ledo, CAS (2008) Características morfológicas, físicas e químicas de frutos de populações de umbu-cajazeira no Estado da Bahia. Rev Bras Frutic. 30(1): 140-147.

CNCFLORA (2015) Centro Nacional de Conservação da Flora: Lista vermelha. Available in: <http://cncflora.jbrj.gov.br/portal/pt-

$\mathrm{br} /$ profile/Swietenia\%20macrophylla>. Accessed on $15 \mathrm{Dec}$ 2015.

Cruz CD (2013) GENES - a software package for analysis in experimental statistics and quantitative genetics. Acta Sci., Agron. 35(3): 271-276.

Decree No. 91.028, March 5th, 1985 (1985) Dispõe sobre o estatuto do índio. Available in: $<$ https://legislacao.planalto.gov.br/legisla/legislacao.nsf/viwT odos/CA7D07B5D6612D33032569FA0073BBD4?OpenDocume nt\&HIGHLIGHT=1,decret\%2091.028> Accessed on 10 Dec 2015.

Dias AB, Carvalho MAPD, Dantas ACVL, Fonseca, VJDA (2011) Variability and characterization of fruits of surinam cherry in municipalities in the state of Bahia. Rev. Bras. Frutic. 33(4): 1169-1177.

Evaristo I, Tenreiro, R, Costa, R (2008) Caracterização de parâmetros biométricos e de ácidos gordos em pinhões de 
populações portuguesas de Pinus pinea L. Silva Lus. 16(1): 119.

FAO (2015) Global Forest Resources Assessment 2015: How are the world's forests changing? FAO Forestry Paper No. 163. UN, Rome. Available in: <http://www.fao.org/3/ai4808e.pdf>. Accessed on 07 Jan 2016.

Fenner M (1993) Seed ecology. London: Chapman and Hall, 151 p.

Freire JM, Pina-Rodrigues FCM, Santos ALF, Pereira MB (2015) Intra-and inter-population variation in seed size and dormancy in Schizolobium parahyba (Vell.) Blake in the Atlantic Forest. Ciênc. Florest. 25(4): 897-907.

Freitas MKC, Coimbra RR, Aguiar GB, Aguiar CBN, Das Chagas DB, De Mello Ferreira W, Oliveira RJ (2012) Variabilidade fenotípica e caracterização morfológica de uma população natural de Hancornia speciosa Gomes. Biosci J. 28(5): 833-841.

Gonçalves LGV, Andrade, FR, Marimon Junior BH, Schossler, TR, Lenza, E, Marimon, BS (2013) Biometria de frutos e sementes de mangaba (Hancornia speciosa Gomes) em vegetação natural na região leste de Mato Grosso, Brasil Rev Cienc. Agrar. 36(1): 31-40.

Gusmão E, Vieira FDA, Fonseca Júnior ED (2006). Biometria de frutos e endocarpos de murici (Byrsonima verbascifolia Rich. ex A. Juss). Rev. Cerne. 12(1): 84-91.

INPE (2015). Instituto de Pesquisas Espaciais: Banco de dados PRODES. Available

in: <http://www.dpi.inpe.br/prodesdigital/prodesmunicipal.php> . Accessed on 15 Dec 2015.

Law 12.651, dated May 25 $5^{\text {th }}, 2012$ (2012). Dispõe sobre a proteção da vegetação nativa; altera as leis n 6.938 , de 31 de agosto de 1981, 9.393, de 19 de dezembro de 1996, e 11.428, de 22 de dezembro de 2006; revoga as leis no S 4.771, de 15 de setembro de 1965, e 7.754, de. Available in: <https://legislacao.planalto.gov.br/legisla/legislacao.nsf/viwT odos/42D0A27D441C7E8203257A0C003E425E?OpenDocume nt\&HIGHLIGHT=1,lei\%2012.651 > Accessed on 10 Dec 2015.

Law 12.727, dated October 17 ${ }^{\text {th }}, 2012$ (2012). Altera a Lei $n$ o 12.651, de 25 de maio de 2012, que dispõe sobre a proteção da vegetação nativa; altera as leis $\mathrm{n}$ - S 6.938, de 31 de agosto de 1981, 9.393, de 19 de dezembro de 1996, E 11.428, de 22 de dezembro de 2006; e revoga as I. Available in:<https://legislacao.planalto.gov.br/legisla/legislacao.nsf/vi wTodos/672336EEE787B97103257A9B0040586F?OpenDocum ent\&HIGHLIGHT=1,lei\%2012.727> Accessed on 10 Dec 2015.

Leão NVM, Araújo EAA, Shimizu ESC, Felipe SHS (2016). Características biométricas e massa de frutos e sementes de Lecythis pisonis Cambess. Encic Biosf. 13(24): 167-175.

Leão NVM, Campos MVA, Felipe, SHS, Cardoso, RS, Shimizu, ESC (2017) Aspectos biofísicos de frutos e sementes e emergência de plântulas de santol. Encic Biosf. 14 (25): 146-157.

Leão NVM, Felipe SHS, Shimizu, ESC, Dos Santos Filho BG, Kato OR, Benchimol RL (2015a) Biometria e diversidade de temperaturas e substratos para a viabilidade de sementes de ipê amarelo. Inf. ABRATES 25(1): 50-54.

Leão NVM, Ohashi ST, Felipe SHS (2015b) Situação atual da pesquisa e produção de sementes de espécies florestais nativas na Amazônia Oriental. In: Fátima Conceição Márquez Piña-Rodrigues; Márcia Balistiero Figliolia; Antonio da Silva. (Org.). Sementes Florestais Tropicais: da ecologia à produção. $1^{\circ}$ ed.Paraná: Associação Brasileira de Tecnologia de Sementes - ABRATES, p. 381-395.

Leão NVM, Ohashi ST, Freitas ADD, Nascimento MRSM, Shimizu ESC, Reis ARS, Galvão Filho AF, Souza D (2011) Colheita de Sementes e Produção de mudas de espécies florestais nativas.
Belém (PA): Embrapa Amazônia Oriental, 47 p. ilust. (Documentos, 374).

Lemes MR, Dick CW, Navarro C, Lowe AJ, Cavers S, Gribel R (2010) Chloroplast DNA microsatellites reveal contrasting phylogeographic structure in mahogany (Swietenia macrophylla King, Meliaceae) from Amazonia and Central America. Trop Plant Biol. 3(1): 40-49.

Lemes MR, Gribel R, Proctor J, Grattapaglia D (2003) Population genetic structure of mahogany (Swietenia macrophylla King, Meliaceae) across the Brazilian Amazon, based on variation at microsatellite loci: implications for conservation. Mol Ecol. 12(11): 2875-2883.

Lourenço IP, Figueiredo RW, Alves RE, Aragão, FA, Moura, CF (2013) Caracterização de frutos de genótipos de muricizeiros cultivados no litoral cearense. Rev Ciênc Agron. 44(3): 499504.

Moraes PLR, Alves MC (2002) Biometria de frutos e diásporos de Cryptocarya aschersoniana Mez e Cryptocarya moschata Nees (Lauraceae). Biota Neotrop, 2(1): 1-11.

Moura NF, Chaves L, Naves RV (2013) Caracterização física de frutos de Pequizeiro (Caryocar brasiliense Camb.) do Cerrado. Rev Árv. 37(5): 905-912.

Mojema R (1977). Hierarquical grouping methods and stopping rules: an evaluation. Comput J. 20: 359-363.

R Development Core Team (2006). A language and environment for statistical computing. Vienna: R Foundation for Statistical Computing, Vienna, Austria.

Sano SM, Vivaldi LJ, Spehar CR (1999). Diversidade morfológica de frutos e sementes de baru (Dipteryx alata Vog.). Pesqui Agropecu Bras. 34(4): 513-518.

Sangalli A, Vieira MC, Scalon, SPQ, Zárate NAH, Silva CB, Ribeiro IS (2012) Morfometria de frutos e sementes e germinação de carobinha (Jacaranda decurrens subsp. symmetrifoliolata Farias \& Proença), após o armazenamento. Rev Bras PI Med. 14(2): 67-275

Scott AJ, Knott MA (1974) A Cluster Analysis Method for Grouping Means in the Analysis of Variance. Biometrics 30(3): 507-512.

Singh D (1981) The relative importance of characters affecting genetic divergence. Indian J Genet Plant Breed. 41(2): $237-$ 245.

Souza DCL, Silva-Mann R, Ferreira RA, Gomes LJ, Almeida TDS, Oliveira ADS, Pereira GS, Gois IB (2013) Produção de frutos e características morfofisiológicas de Schinus terebinthifolius Raddi., na região do baixo São Francisco, Brasil. Rev Árv. 37(5): 923-932.

Sudré CP, Rodrigues R, Gonçalves LSA, Martins ER, Bento CS (2011) Coleta, caracterização e divergência fenotípica de frutos de fava-d'anta. Rev Caatinga. 24(4): 1-8

Teixeira RA, Pedrozo CÂ, Costa EKL, Batista KD, Tonini H, Pessoni LA (2015) Correlações e divergência fenotípica entre genótipos cultivados de castanha-do-Brasil. Sci For. 43(107): 523-531.

Vasconcelos ES, Reis MS, Sediyama T, Cruz CD (2012) Estimativas de parâmetros genéticos da qualidade fisiológica de sementes de genótipos de soja produzidas em diferentes regiões de Minas Gerais. Semin Ciênc Agrár. 33(1): 65-76.

Vencovsky, R; Barriga, P (1992) Genética biométrica no fitomelhoramento. Ribeirão Preto: Rev Bras Gen. 486p.

Zuffo AM, Andrade, FR, Júnior Joacir MZ (2014) Caracterização biométrica de frutos e sementes de baru (Dipteryx alata Vog.) na região leste de Mato Grosso, Brasil. Rev Cienc Agrar. 37(4): 463-471. 